Book 2.0

Volume 11 Number 1

(C) 2021 Intellect Ltd Interview. English language.

https://doi.org/10.1386/btwo_00048_7

\title{
INTERVIEW
}

\author{
ELAINE GOLD
}

MARK TURIN

\section{Interview between Elaine Gold and Mark Turin}

\section{ABSTRACT}

This interview between the Director of the Canadian Language Museum, Elaine Gold, and Board Member Mark Turin explores the history and goals of a small museum that achieves national reach through travelling exhibits dedicated to an intangible subject matter - language.

Mark Turin (MT): What is the Canadian Language Museum?

Elaine Gold (EG): The Canadian Language Museum (CLM) is a small museum dedicated to promoting knowledge about the many different languages spoken in Canada. The Museum assumes a particular responsibility for raising awareness about the over 60 Indigenous languages spoken in Canada.

MT: What experiences led you to establishing the museum, and how did you start it?

\section{KEYWORDS}

language

museum

Canada

Indigenous

exhibit

bilingual 


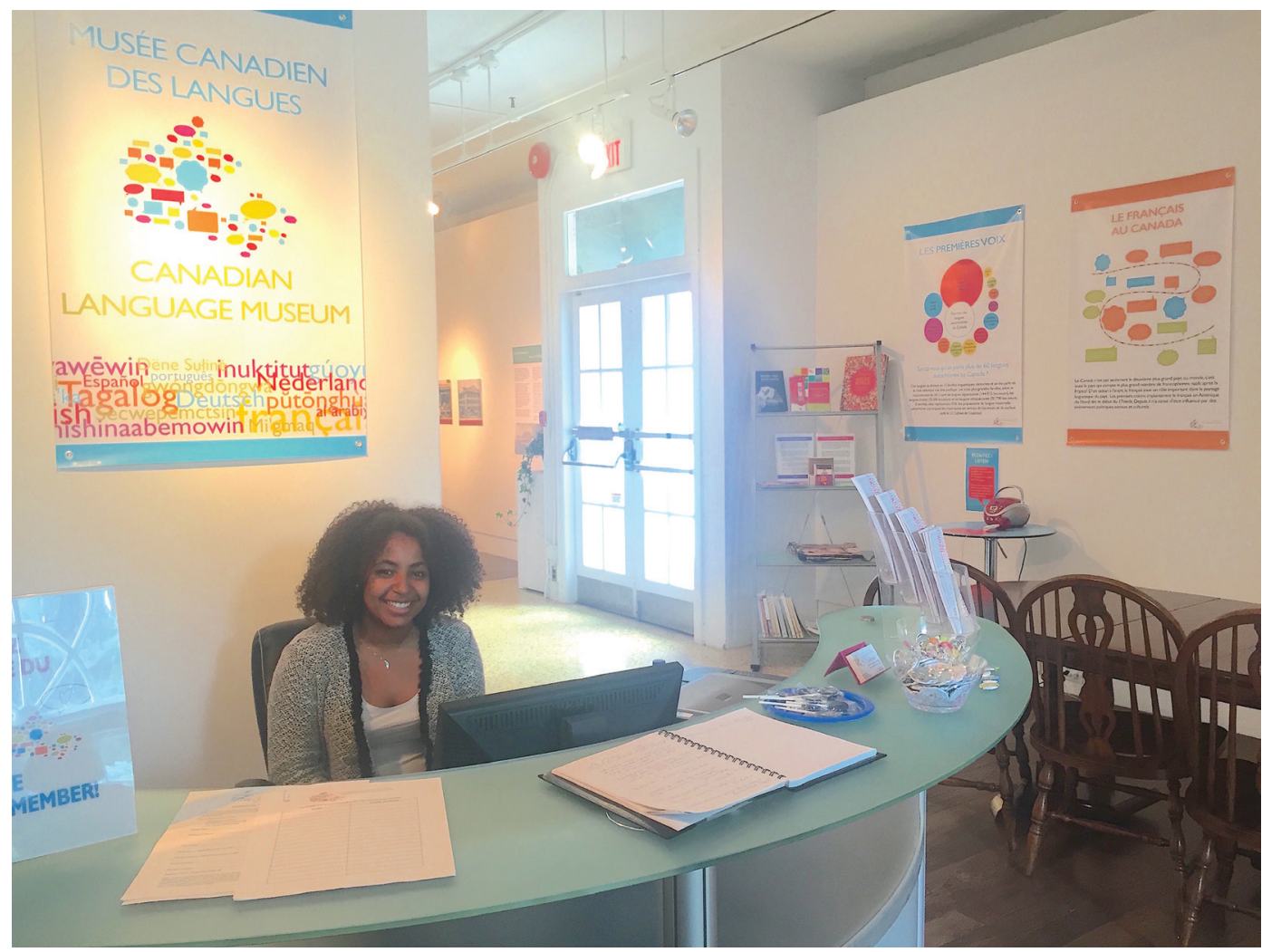

Figure 1: Entrance to Canadian Language Museum, Glendon Gallery. Intern Hilel Essadi. May 2017.

1. The LINGUIST List is operated at the Department of

Linguistics at Indiana University. The aim of the list is to provide a forum where academic linguists can discuss linguistic issues and exchange linguistic information. Its main and oldest feature is a premoderated electronic mailing list, now with thousands of subscribers all over the world, where queries and their summarized results, discussions, journal table of contents, dissertation abstracts, calls for papers, book and conference announcements,
EG: In 2007, I was teaching linguistics at the University of Toronto and I saw a posting on LINGUIST List ${ }^{1}$ with the title 'An international language museum for Denmark'. I thought 'Language museum! If any country needs a language museum, it's Canada'. I then began researching language museums around the world and started raising the possibility of a language museum with other Canadian linguists (Gold 2019).

My background, which always seemed ridiculously eclectic for a linguist, was actually ideal for starting a museum. While my Ph.D. is in linguistics, I have an MA in art history and had worked in several museums, including the Itsanitaq Museum in Churchill, Manitoba and the Winnipeg Art Gallery, in their Inuit Art collection. I also had experience in arts administration from some years working as manager for small dance companies and as a consultant to the Ontario Arts Council. And I had relevant experience as a board member on several arts organizations as well. So, the challenges of starting a small arts organization were familiar to me.

For several years I led discussions at the annual conference of the Canadian Linguistic Association about the possibility of starting a language museum. While there was considerable enthusiasm for the idea, there was also trepidation about how to best proceed. There was debate as to whether it should be online only, or have 'real' exhibits, and reasonable questions about how it 
could be funded. In 2011, I decided that the best way to resolve these issues was to leap in. A small group of linguists sat down with me to hammer out the name and goals of the museum.

MT: The Canadian Language Museum is unusual in that is has a home base located on Glendon College campus of York University in Toronto - but the exhibits for which it is known have travelled far and wide. What does it mean to have a mobile and portable museum?

EG: We are very fortunate that we now have a beautiful home base on Glendon College campus. However, when we first established the museum, we had no exhibit space and so decided that we would reach our audience through travelling exhibits. We developed a model for our exhibits that is light, fairly inexpensive, easily shipped, adaptable to a wide variety of spaces and quite simple to install.

We were delighted to discover that there is huge interest in the Canadian public in language. Canada is a diverse country, and not only are people proud of their own languages and heritage but they are genuinely excited about learning about other languages as well. We've had very enthusiastic responses to our exhibits and a constant stream of suggestions about other languages we should focus on. We have strong followings on our social media accounts: one software notices and other useful pieces of linguistic information are posted (LINGUIST List n.d.).

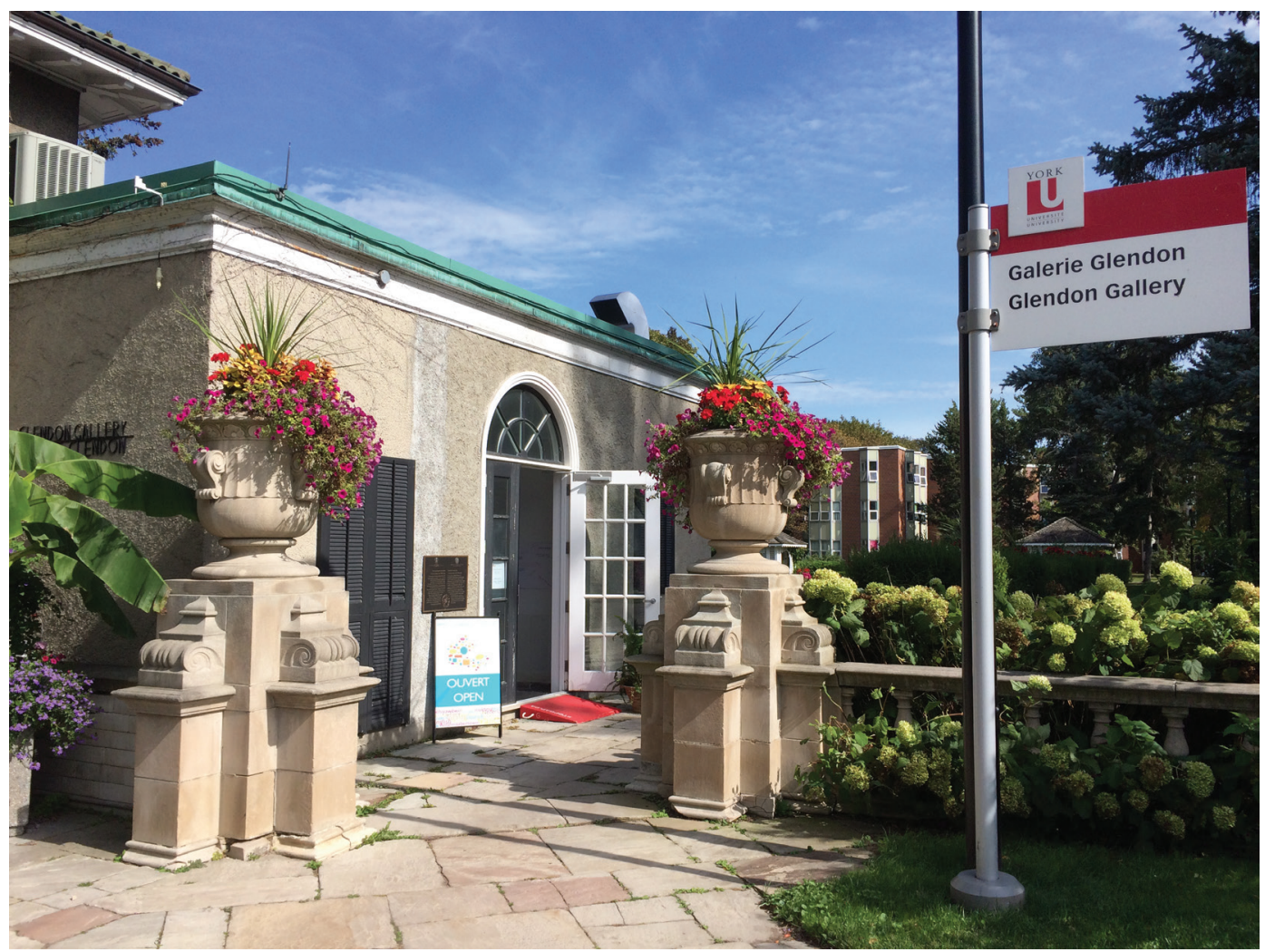

Figure 2: Glendon Gallery exterior September 2019. 
recent Facebook posting that illustrated the Algonquian language family had over 100,000 views.

Right now, there is a particular interest across the country in Indigenous languages in particular. Canada's Truth and Reconciliation Commission published their Calls to Action in 2015, and their work has raised awareness of harm done to Indigenous culture and to Indigenous languages over the centuries by colonial practices (Pine and Turin 2017). In response to these Calls to Action, Bill C-91, the Indigenous Languages Act, was enacted in June 2019 and established an Office of the Commissioner of Indigenous Languages. The CLM has participated in symposia focused on Indigenous language rights and supports language revitalization efforts by bringing information about the rich variety of Indigenous languages to a broad public (Oxford 2019).

In order to make the exhibits as accessible as possible, we do not charge an entrance fee to our exhibit space. Entrance to most of the venues where our travelling exhibits are shown is free as well. The CLM's exhibits have been hosted at over 30 university and college campuses, at more than 25 libraries across the country and been part of over 35 conferences, symposia and festivals. Many venues have hosted several exhibits over the years. It is especially gratifying to be able to bring these exhibits to where people live, in small and large communities across the country. Our exhibits are shown in public spaces such as libraries, community centres, municipal buildings and schools - places

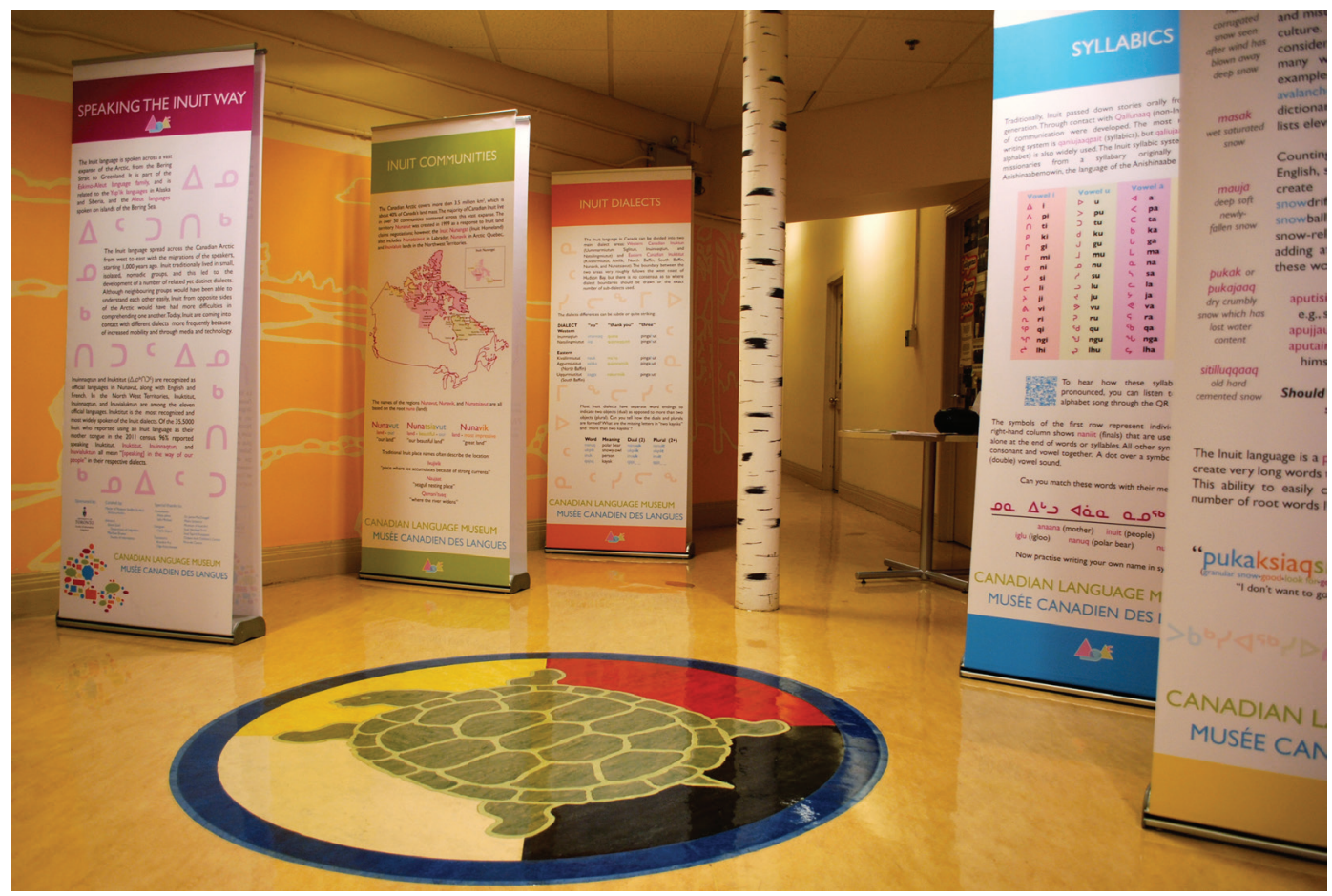

Figure 3: Speaking the Inuit Way. CLM exhibit in Centre for Indigenous Studies, University of Toronto, June 2014. Photographer Katharine Snider-McNair. 


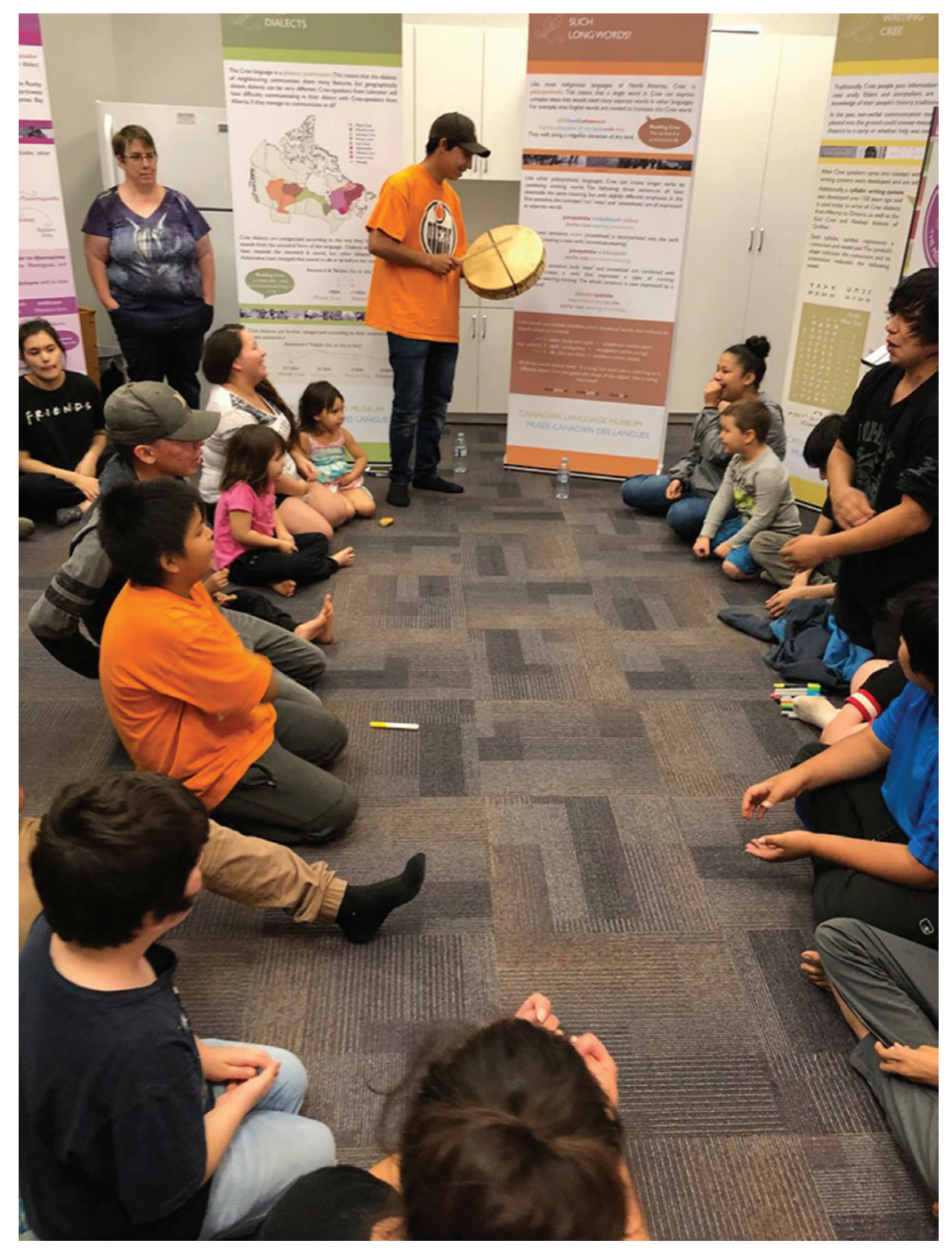

Figure 4: Cree: The People's Language. CLM Exhibit in Ft. Vermilion Community Library. September 2019. Permission from library.

where we can reach a very wide audience, including those who might never visit a conventional museum.

MT: What are the different CLM exhibits that you've curated?

EG: We have created eight bilingual (French/English) travelling exhibits. There are specific exhibits about Canada's two official languages and the two largest Indigenous languages in Canada, Cree and Inuktitut. Other exhibits provide introductions to a variety of languages and language issues (Guzmán 2020):

Canadian English, Eh?

Speaking the Inuit Way 


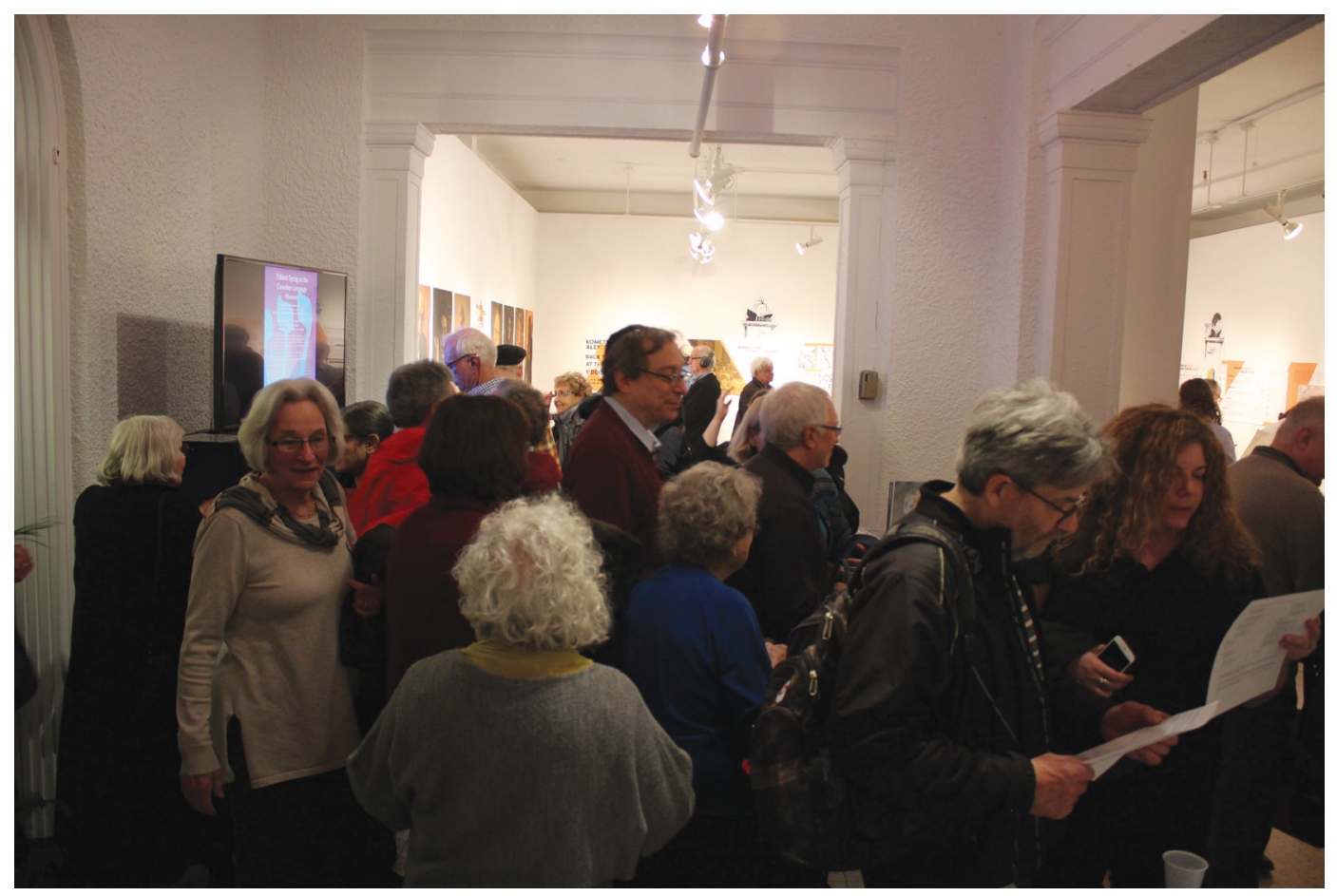

Figure 5: Yiddish Spring. CLM Exhibit in Glendon Gallery. April 2019. Photographer Jocelyn Kent.

Le français au Canada

Cree: The People's Language

A Tapestry of Voices: Celebrating Canada's Languages

Read between the Signs: 150 Years of Language in Toronto

Beyond Words: Dictionaries and Indigenous Languages

Sign Languages of Canada

We have a virtual exhibit on our website Messages from the Mosaic and a video Two Row Wampum: Preserving Indigenous Languages in Toronto. In our gallery space we have hosted a number of language-related art and photography shows, workshops and dance performances. We also commissioned a Berlin-based composer, Paul Brody, to create a sound installation for the gallery space: The Music of Yiddish Blessings and Curses.

MT: Which worked best and what challenges did you encounter in their creation and dissemination?

EG: In creating an exhibit about a language, one challenge is making the exhibit accessible to a wide audience. How do you make an exhibit about a language interesting to viewers who might know nothing about it and perhaps didn't yet know that they were interested? What information do you include and what omit? How do you deal with dialect variation, so that viewers from across this very large country can still relate to the content? 
A big question for us was how to incorporate audio into a lightweight exhibit that will be hosted in very public settings. We have tried using CD players, programmed tablets, QR codes and small push-button speakers. While you can incorporate a lot of information on a tablet or through a QR code, my favourites are still small push-button speakers. Visitors of all ages like to push buttons!

Of course, we have the challenge of ensuring that the exhibit content is accurate and respectful. We do this through working both with language experts and with native speakers of the particular languages involved.

When we first moved into Glendon Gallery in 2016, we were so excited to have actual walls, that we created our first and only wall-hung exhibit Read Between the Signs: 150 Years of Language in Toronto. We discovered that although this exhibit looks beautiful, it is much more difficult to tour than the other exhibits, which use freestanding banner stands to display the text. The banner stands can adapt easily to odd-shaped spaces; while a wall-hung exhibit needs quite a bit of continuous blank wall!

MT: Have any of your exhibitions travelled beyond Canada?

EG: Our focus has been on having the exhibits travel in Canada, and so they have only been out of the country twice. I took our first exhibit, Canadian English, Eh? to a large academic conference in Boston, the Linguistic Society of America (LSA) conference, where I found that most of the interest came from the Canadians present. More recently I took the exhibit Cree: The People's Language to the International Year of Indigenous Languages 2019:

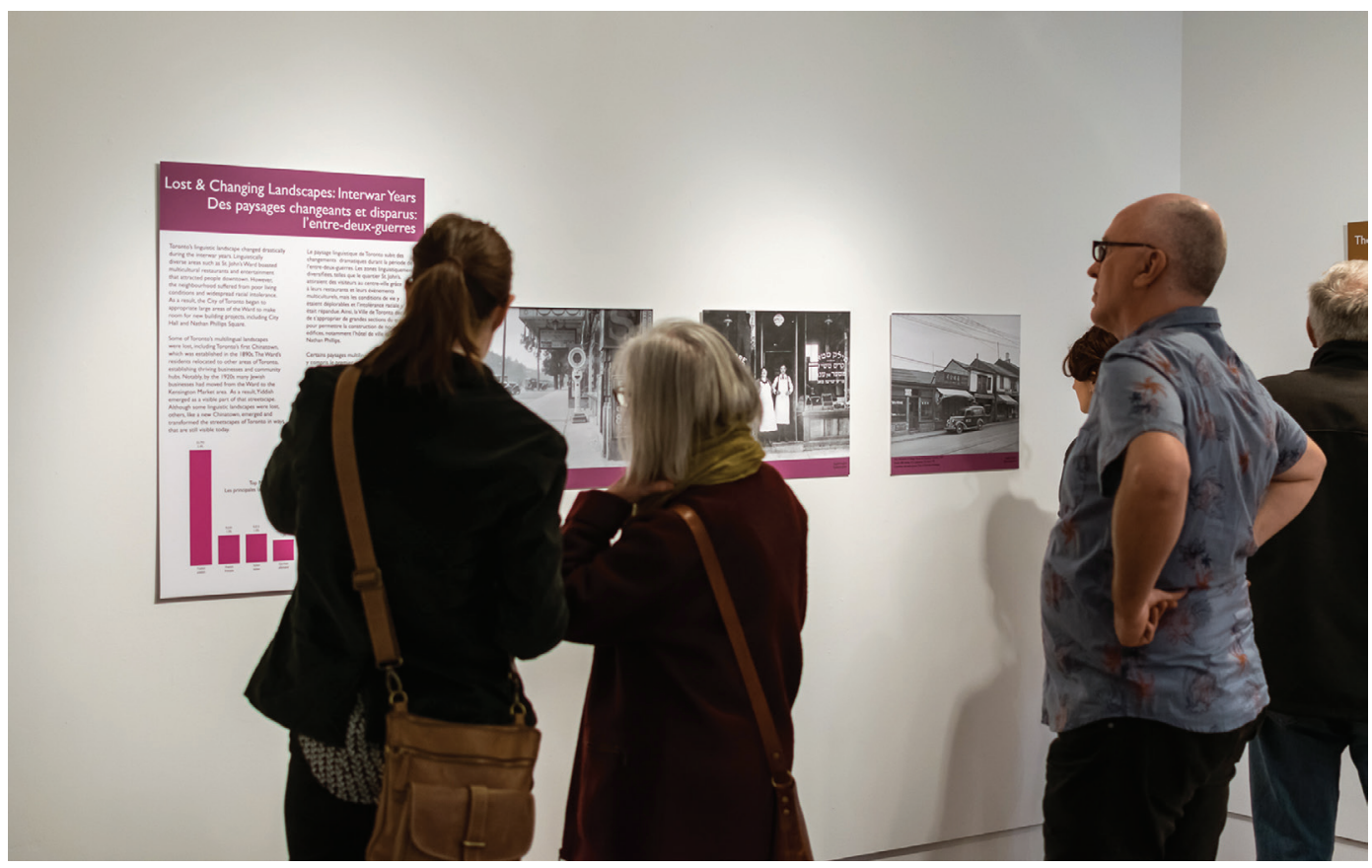

Figure 6: Read Between the Signs: 150 Years of Language in Toronto. CLM Exhibit in Glendon Gallery. May 2017. Permission from photographer Jake Malone. 


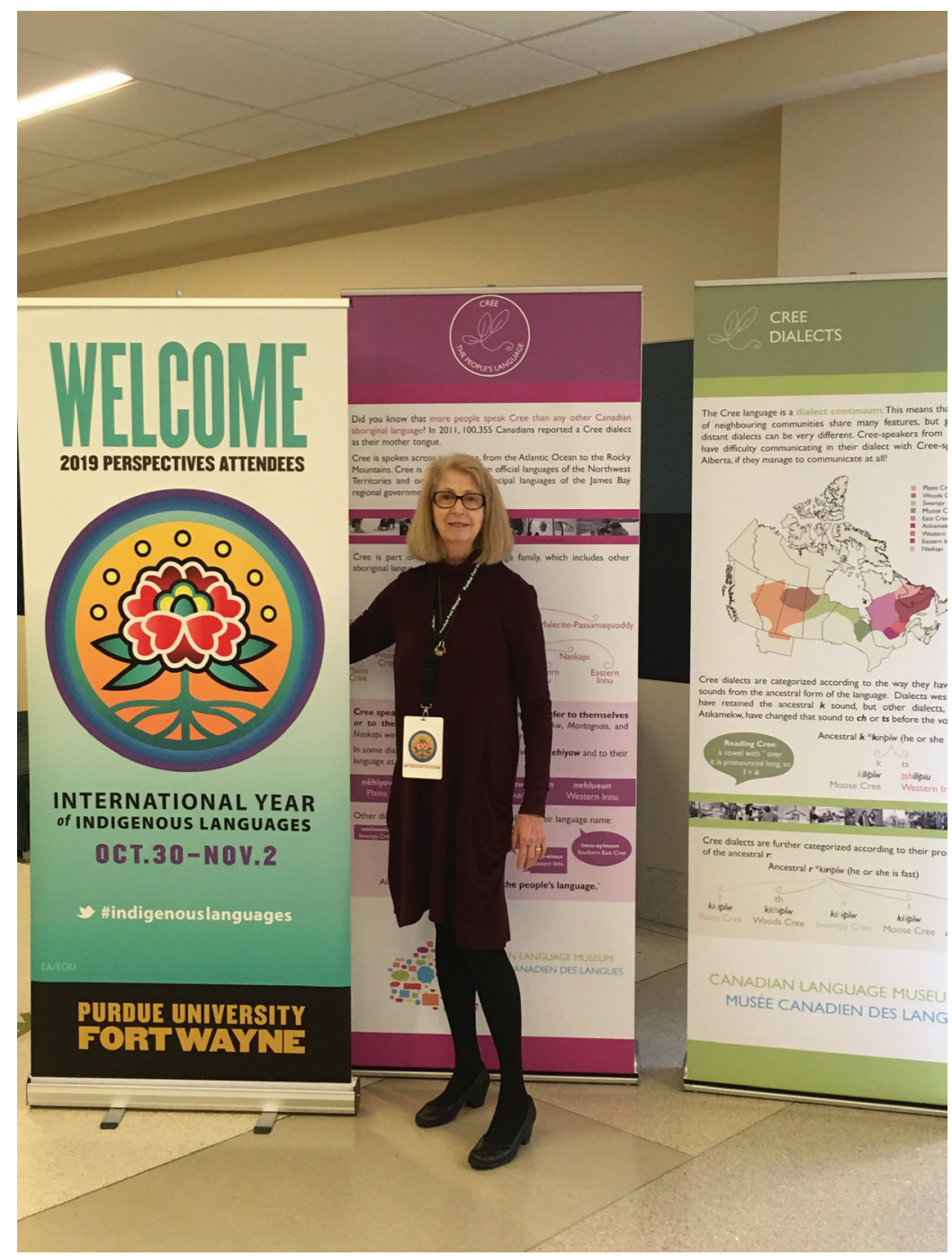

Figure 7: Elaine Gold with exhibit Cree: The People's Language at the International Year of Indigenous Languages conference, Ft. Wayne, Indiana. October 2019.

Perspectives Conference, an international conference held in Ft. Wayne, Indiana, where it was very well received.

MT: I am honoured to have recently joined the CLM board as a member. Can you talk a little about governance and to whom the CLM is accountable?

EG: Not surprisingly, our board has been composed primarily of linguists or those involved with teaching or researching languages. We have Indigenous board members as well as several members involved with research and revitalization of Indigenous languages. We have representation from across the country (and beyond) and have two Francophone members.

As with every charitable organization, the board of directors is ultimately responsible for the CLM's continuing operation. While I, as Director, take care 
of the day-to-day running of the Museum, the board advises on policy decisions and long-term planning.

MT: Are there other language museums from which you have drawn inspiration, or have perhaps been established following the lead and example set by the CLM?

EG: The CLM is the only language museum in Canada and there are very few language museums in the world. Of those that exist, most are devoted to a single national language or writing system, such as the Museum of the Hungarian Language, the Afrikaanse Taalmuseum in South Africa or the National Hangeul Museum in Seoul. Others focus on more general and less national language issues, such as languages in general (Mundolingua in Paris), writing systems of the world (the Museé Champollion in Figeac) or planned languages (the Esperanto Museum in Vienna). The CLM is unique in having a mandate of promoting the many different languages spoken in our country.

When I was first starting out, I looked to the National Museum of Language in the USA as an example of a small language museum, and I tried to learn both from their strengths and weaknesses. The CLM is a member of both the Ontario Museum Association and the Canadian Museum Association, and I have learned a lot about directing small museums from their members (Gold 2017). I have also attended two international meetings of language museums and am a founding member of the International Network of Language Museums. I have been inspired by programmes and exhibits in other language museums, such as the interactive exhibits in the Lithuanian Hearth, among others. I am in close communication with the founders of the new Eurotales project in Italy, and they have taken ideas from the CLM for their own work. In December 2019, the first book about language museums was published, Museums of Language and the Display of Intangible Cultural Heritage (Sönmez et al. 2020) and includes a chapter I wrote entitled 'The Canadian Language Museum: Developing travelling exhibits' (Gold 2020).

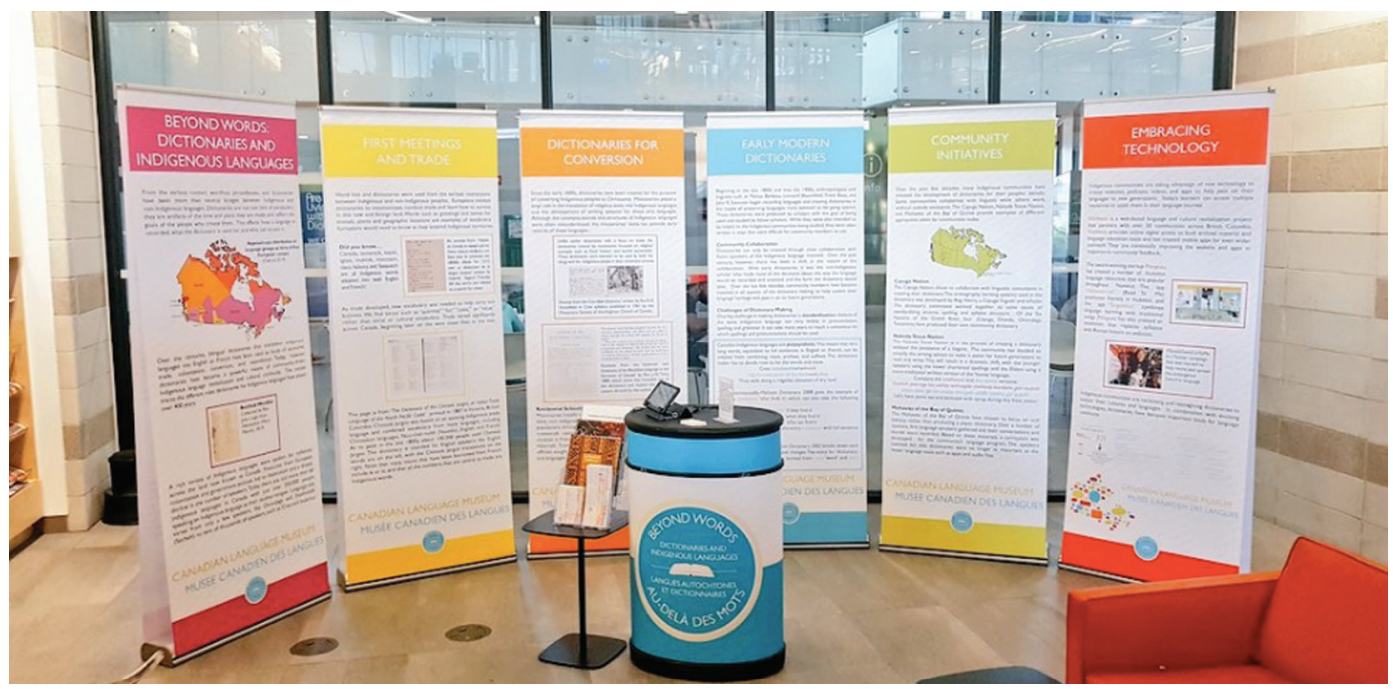

Figure 8: Beyond Words: Dictionaries and Indigenous Languages. CLM Exhibit in Markham Public Library. July 2019. Permission from library. 
MT: How has the work of the CLM been impacted by COVID-19 and the global pandemic? Have you or are you exploring opportunities for online exhibits?

EG: Most of the funding for the CLM comes from rental fees for our exhibits. With COVID-19, the rentals of our exhibits have pretty well stopped, since the public spaces where they would be displayed are closed. Of course, our own exhibit space is closed, and so we are not able to invite the university community and the public into our gallery and we cannot host the events that we would usually be scheduling. Unfortunately, we don't qualify for any of the government funds available to museums for COVID-19 support, so we are struggling financially.

We have continued regular e-communication with our members and have invited them to visit our virtual exhibit Messages from the Mosaic and our video and blog postings. We are delaying the launch of our most recent exhibit Sign Languages of Canada and of the art exhibit Anthem: Expressions of Canadian Identity until we are able to welcome visitors into our exhibit space again. We are in the process of creating an exciting 3D virtual exhibit based on the Sign Languages of Canada exhibit.

MT: How have students been involved in the work of the Canadian Language Museum?

EG: Working with students has been central to the CLM's operations from the beginning. Soon after the CLM was founded, I consulted with the Master of Museum Studies programme at the University of Toronto and discovered that students in the second-year exhibitions course are placed in museums and galleries to work on curatorial projects. For the past ten years, I have visited that class in September to pitch my project for that year, and I have been fortunate to have had between one and four students choose to work with me each year. They bring an enormous amount of creativity, ingenuity, design and research skills to the CLM's exhibits. Over the past year I worked with three museum studies students who created a catalogue, web exhibit (Anthem: Expressions of Canadian Identity n.d.) and installation plan for the art exhibit Anthem: Expressions of Canadian Identity.

In our early years, University of Toronto students worked on the website, newsletters and blog. Since our move to Glendon in 2016, the CLM has forged close ties with a variety of groups on the Glendon campus. Students in Translation Studies have translated the last four exhibits from English to French. Students in the Histoire Vivante/Public History course were placed at the Museum for a semester where they created the Two Row Wampum video and a video of interviews to accompany the Sign Languages exhibit. This year, two students from that course created an online survey to complement the Anthem exhibit, which allowed for wide community response to questions raised about the meaning and suitability of the Canadian anthem's lyrics to our multicultural population.

Linguistics club members meet and volunteer in the museum, and student fellows in the Robarts Centre of Canadian Studies work on language-related projects to share with the community. Indigenous groups on campus have presented programmes in the Museum space, and I am active in the Centre for Research on Language and Culture Contact (CRLCC) at Glendon College. The Museum space is used for events for alumni and prospective students. This very close collaboration between the CLM and the Glendon College community has been of great benefit to both. 


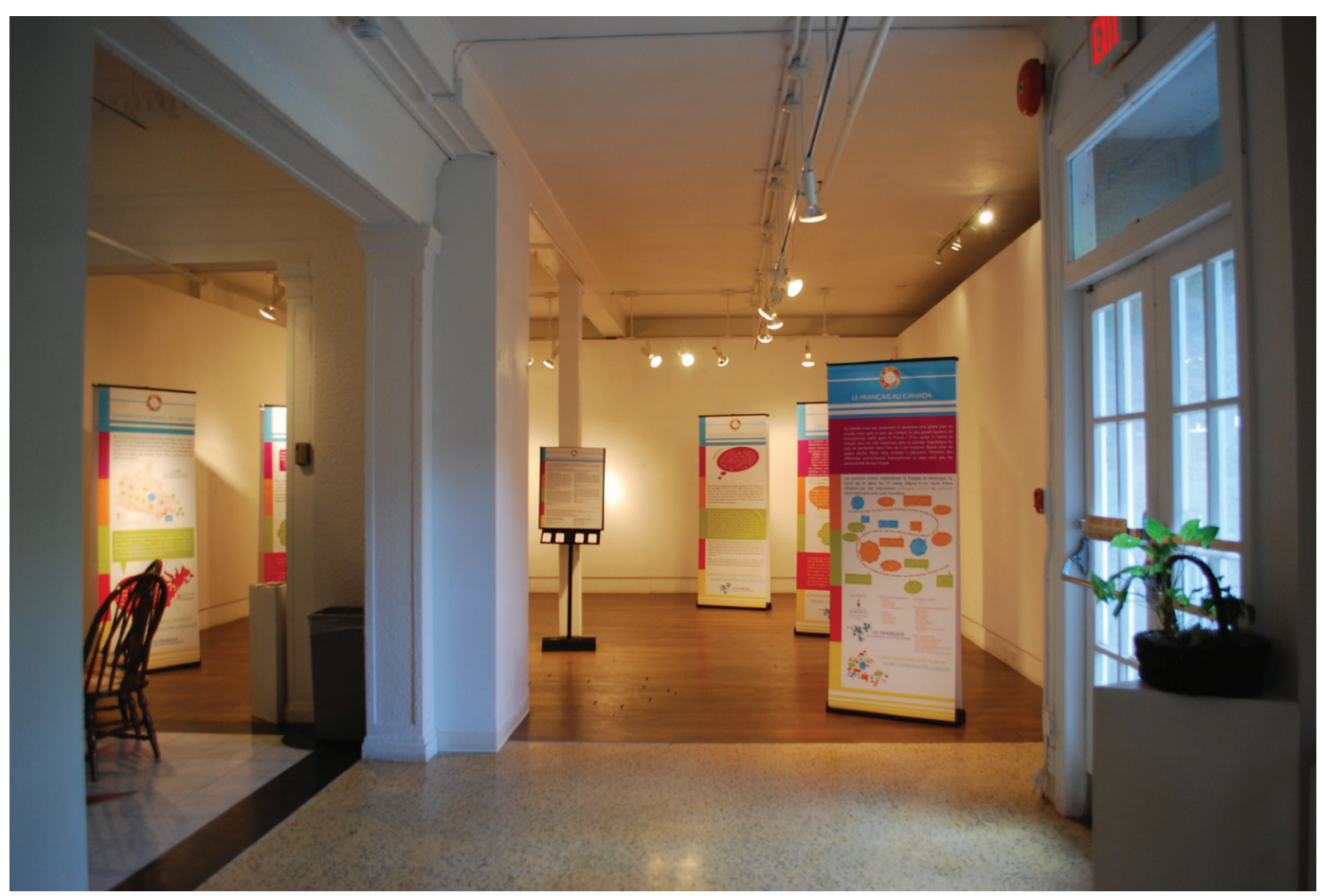

Figure 9: Le français au Canada. CLM Exhibit in the back exhibit space. Canadian Language Museum, Glendon Gallery. 2016.

MT: I understand that 2021 will be the CLM's tenth anniversary. What are your hopes for the next ten years for the CLM?

EG: We have many exciting projects planned for the coming years, including: an exhibit about the third largest Indigenous language in Canada, Anishinaabemowin (Ojibwe) and about two large immigrant languages: Italian and Chinese. I am also planning an exhibit about three Indigenoussettler contact languages: Michif, Bungi and Chinook Jargon. Michif is a unique contact language in that the two languages involved, French and Cree, account for different grammatical aspects: the verb system is primarily Cree, while the nouns are primarily French. Michif is considered the heritage language of the Métis people. ${ }^{2}$ Bungi is no longer spoken and is little known, even within Canada: it resulted from contact between the Scots English of men working for the Hudson's Bay Company with Indigenous languages, mostly Cree. Chinook Jargon had its heyday in the late nineteenth century where it functioned as a trade language in the Pacific Northwest. It combined both French and English with West Coast Indigenous languages, primarily Chinook.

Over the next ten years, we hope to raise the profile of the CLM, and extend our touring to many new venues, including isolated and small Indigenous communities. We hope to strengthen our ties to the Glendon community and to improve the visitor experience for those who come to the gallery space.

My main goal remains financial sustainability so that this work of promoting information about Canada's languages, and in particular, about Canada's
2. See Bouvier (2019) in this journal for a personal exploration of Michif identity and language. 
Indigenous languages, can continue. I am very gratified that in the last month alone, three different language groups approached us for advice on creating language exhibits. If we can help community groups and small organizations create their own exhibits about their languages, the CLM will be making a valuable contribution to Canadian culture and to the process of Reconciliation.

\section{REFERENCES}

Anthem: Expressions of Canadian Identity (2021), Canadian Language Museum, online exhibition, https://www.anthemexhibit.ca/. Accessed 8 June 2021.

Bouvier, Victoria (2019), 'Ni kaakiihtwaamaan itootamihk waapamishoon aan mii wiichaytoowuk: I am practice reflected in relationships', Book 2.0, 19:1\&2, pp. 31-44, http://doi.org/10.1386/btwo_00004_1. Accessed 8 June 2021.

Gold, Elaine (2017), 'Ontario's language heritage', Heritage Matters, Autumn, p. 9, http://online.fliphtml5.com/qnqes/bevg/\#p=1. Accessed 6 July 2021.

Gold, Elaine (2019),'A brief history of the Canadian Language Museum or how a posting on LINGUIST List changed my life', Lingoblog, 11 December, https://www.lingoblog.dk/en/a-brief-history-of-the-canadian-languagemuseum-or-how-a-posting-on-linguist-list-changed-my-life/. Accessed 8 June 2021.

Gold, Elaine (2020), 'The Canadian Language Museum: Developing travelling exhibits', in M. J.-M. Sönmez, M. W. Gahtan and N. Cannata (eds), Museums of Language and the Display of Intangible Cultural Heritage, Abingdon: Routledge, pp. 134-52.

Guzmán, Maria Constanza (2020), 'Decolonizing the museum: An interview with Elaine Gold, director of the Canadian Language Museum (CLM)', Tusaaji: A Translation Review, 7:1, pp. 95-100, https://tusaaji.journals.yorku. ca/index.php/tusaaji/article/view/40389/36576. Accessed 8 June 2021.

LINGUIST List (2007), 'International Language Museum in Denmark', LINGUIST List, 7 June, https://linguistlist.org/issues/18/18-1750/. Accessed 2 August 2021.

Oxford, Will (2019), in E. Gold (ed.), Indigenous Languages in Canada, Toronto: Canadian Language Museum, https://www.languagemuseum.ca/indigenous-languages-in-Canada. Accessed 8 June 2021.

Pine, Aidan and Turin, Mark (2017), 'Language revitalization', in M. Aronoff (ed.), Oxford Research Encyclopedia of Linguistics, New York: Oxford University Press, http://doi.org/10.1093/acrefore/9780199384655.013.8. Accessed 8 June 2021.

Sönmez, Margaret J.-M., Gahtan, Maia Wellington and Cannata, Nadia (eds) (2020), Museums of Language and the Display of Intangible Cultural Heritage, Abingdon: Routledge.

\section{CONTRIBUTOR DETAILS}

Elaine Gold initiated the founding of the Canadian Language Museum and oversees its operations. She brings to her work at the CLM a Ph.D. in linguistics, an MA in art history and strong experience in arts administration and curatorial work. She taught linguistics at the University of Toronto for over twenty years and at Queen's University for seven. Her research focused on Canadian English, Yiddish, Bungi and language contact. She has lived in central, western and northern Canada, and is dedicated to promoting and protecting this country's rich language heritage. She is the recipient of the 
2019 National Achievement Award from the Canadian Linguistic Association for her work with the Canadian Language Museum.

E-mail: director@languagemuseum.ca

(D) https://orcid.org/0000-0002-4798-6036

Mark Turin is an anthropologist, linguist and occasional radio presenter, and an associate professor at the University of British Columbia. He is cross-appointed between the Institute for Critical Indigenous Studies and the Department of Anthropology. Before joining UBC, he was an associate research scientist with the South Asian Studies Council at Yale University, and the founding programme director of the Yale Himalaya Initiative. He has also held research appointments at Cornell and Leipzig universities, as well as the Namgyal Institute of Tibetology in Sikkim, India. From 2007 to 2008, he served as chief of translation and interpretation at the United Nations Mission in Nepal (UNMIN). For over twenty years, his research focus has been the Himalayan region (particularly Nepal, northern India and Bhutan), and more recently, the Pacific Northwest. He writes and teaches on language reclamation, revitalization, documentation and conservation; language mapping, policies, politics and language rights; orality, archives, digital tools and technology. $\mathrm{He}$ is the author or co-author of four books, three travel guides, the editor of twelve volumes, and he edits a series on oral literature.

E-mail: mark.turin@ubc.ca

(D) http://orcid.org/0000-0002-2262-0986

Elaine Gold and Mark Turin have asserted their right under the Copyright, Designs and Patents Act, 1988, to be identified as the authors of this work in the format that was submitted to Intellect Ltd. 